\title{
Misperception of entrepreneurship and its consequences for the perception of entrepreneurial failure - the German case
}

Andreas Kuckertz, Elisabeth S.C. Berger and Alicia Prochotta Entrepreneurship Research Group, University of Hohenheim, Stuttgart, Germany

\begin{abstract}
Purpose - This study aims to investigate how Germans' misperceptions of the nature of entrepreneurship influence their attitudes towards entrepreneurial failure.

Design/methodology/approach - Adopting a multivariate regression analysis, the study used data collected from a commercial online market research panel $(N=2,027)$ reflecting the overall German working population. Attitudinal items on business failure were used to measure the study variables. The study controlled for age, education, employment status, gender, income, whether the respondent knows a failed entrepreneur and the German federal state in which the respondent resides.

Findings - The findings suggest that reservations about failed entrepreneurs become stronger as misperceptions of the nature of entrepreneurship worsen. The results also show that failure reservations vary regionally over the 16 German federal states.

Practical implications - Nationwide efforts regarding the stimulation of entrepreneurship and the acceptance of entrepreneurial failure are insufficient for removing failure reservations, as they neglect regional cultural differences. The results suggest that it is not enough just to invest in efforts to create a failure-friendly culture, and that a better general education about the realities of entrepreneurship is a prerequisite.

Originality/value - The study generates insights into how the overall population in an innovation-driven economy perceives entrepreneurship and entrepreneurial failure. Moreover, the work delves into the reasons why parts of German society reject failed entrepreneurs. Hence, this study can aid the drafting of effective policy initiatives at the regional and national levels.
\end{abstract}

Keywords Entrepreneurship, Failure, Perception, Germany, Culture

Paper type Research paper

\section{Introduction}

Why do some countries such as Germany never quite fulfil their obvious entrepreneurial potential? Researchers, policy-makers and individuals widely recognise the great importance of entrepreneurship for economic development, job creation and innovation in a country (Lee et al.,2011). In contrast to other innovation-driven economies, such as the USA, the number of companies founded in Germany have been falling for several years, despite an economy that was strong and stable for a long time, which should actually benefit entrepreneurship (Kalden et al., 2017; KfW, 2018). This places Germany among the countries with the lowest

(C) Andreas Kuckertz, Elisabeth S.C. Berger and Alicia Prochotta. Published by Emerald Publishing Limited. This article is published under the Creative Commons Attribution (CC BY 4.0) licence. Anyone may reproduce, distribute, translate and create derivative works of this article (for both commercial and non-commercial purposes), subject to full attribution to the original publication and authors. The full terms of this licence may be seen at http://creativecommons.org/licences/by/4.0/legalcode.

The authors are indebted to Martin P. Allmendinger and Christoph Mandl for numerous discussions on the phenomenon of entrepreneurial failure and for their assistance during the conceptualization of this study. Data collection was generously supported by the Karl Schlecht Foundation, Aichtal, Germany.

Author contributions: Andreas Kuckertz: Conceptualization, formal analysis, resources, data curation, writing - review and editing, supervision. Elisabeth S.C. Berger: Conceptualization, writing - original draft, project administration. Alicia Prochotta: Writing - original draft..

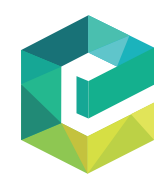

Received 10 February 2020

Revised 23 June 2020

5 August 2020

Accepted 10 August 2020

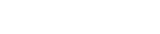


IJEBR

26,8

1866 rate of business start-ups worldwide and prompts questions about the potential reasons for this apparent inconsistency. According to the latest results of the Global Entrepreneurship Monitor (GEM) and the GEM country reports, Germany ranks 28th out of 33 comparable high-income countries with a start-up rate of $7.6 \%$. The large gap between Germany and countries with similarly high incomes, such as the USA and Canada, whose share of founders among the 18- to 64-year-old population in 2019 was 2-5 times higher than that of Germany, is particularly remarkable (Sternberg et al., 2020). The economic conditions of a country or region do not influence the level of entrepreneurial activity alone (e.g. Díez-Martín et al., 2016), instead the societal and cultural context in which entrepreneurship takes place also affects the entrepreneurial activity (e.g. Cardon et al., 2011; Grichnik, 2008; Kuckertz et al., 2015; Ruda et al., 2012).

The failure culture, or more precisely the attitude with which failed entrepreneurs are encountered in a country, and the institutional settings resulting from this attitude are, for example, important framework conditions for entrepreneurial endeavours (e.g. Cope et al., 2004; Grichnik, 2008; Kibler et al., 2017; Landier, 2005; Mittelstands Monitor, 2007). In contrast to Anglo-Saxon countries, Germany has a reputation for not granting failed entrepreneurs a second chance and thus making it more difficult for them to recover from failure or to start subsequent new ventures (Mittelstands Monitor, 2007). Furthermore, Germans generally are more risk-averse and afraid of failure than some other nationalities (Sternberg et al., 2004).

However, this fear might have been ill-founded for many years, given that only a minor share of discontinued businesses eventually became insolvent (KfW, 2018) and the number of insolvencies has been decreasing for some years - especially among new ventures (Creditreform, 2017). This situation reveals a lack of understanding what could explain the German society's fearful attitude towards failure - or failure reservations - regarding the founding of new ventures, despite the low numbers of actual failures. Shedding light on the antecedents of German's failure reservations becomes even more important in light of the COVID-19 pandemic. The pandemic has caused a worldwide health and economic crisis, putting pressure on entrepreneurial family business (Kraus et al., 2020), innovative start-ups (Kuckertz et al., 2020) and the solo self-employed (Block et al., 2020) and is likely to cause rising failure rates in Germany and around the globe.

Current entrepreneurship research on cultural contexts shows great advances, for example, with regard to how cultural dimensions that prevail in a country affect the activities of nascent, opportunity-driven entrepreneurs (e.g. Kuckertz et al., 2015; Yan and Guan, 2019) or the level of entrepreneurship within a country in general (e.g. Fernández-Serrano et al., 2018). However, knowledge of how public audiences from different countries or regions perceive the nature of entrepreneurship remains limited, and it is unclear how these perceptions influence the attitudes towards entrepreneurial failure in terms of failure reservations and how perceptions and attitudes differ within particular regions of a country, rather than across the country as a whole. The present paper addresses this lack of research by scrutinising a representative sample of the overall German population and by answering the following research questions: How do Germans' perceptions of the nature of entrepreneurship influence their attitudes to entrepreneurial failure? And, do these perceptions and attitudes differ regionally? The nature of entrepreneurship refers to entrepreneurial opportunity recognition and exploitation (Kuckertz et al., 2017) under risk, making entrepreneurial failure not only an option but also a central and natural element of any entrepreneurial activity. An analysis of the responses from 2,027 survey participants suggests that failure reservations are particularly attributable to misperceptions of the nature of entrepreneurship, and that failure reservations vary within the German federal states.

The present work offers a number of important contributions. In using the example of Germany, the evaluator perspective on entrepreneurial failure is advanced (Shepherd and Patzelt, 2017) by generating insights into how both entrepreneurship and entrepreneurial 
failure are perceived by the overall population in an innovation-driven economy. The present work also delves into the reasons why parts of German society reject entrepreneurs whose businesses have failed. Hence, the study suggests an indirect approach to removing reservations about entrepreneurial failure by educating people on the realities of entrepreneurship. In this regard, the present study could aid the drafting of effective policy and educational initiatives at the national and regional levels within a country. Policymakers and educators should pay greater attention to the individual perceptions of entrepreneurship as an important determinant of entrepreneurial attitudes and the attitudes to certain potential outcomes of entrepreneurial activity, such as entrepreneurial failure, to enhance a country's entrepreneurial culture while educating people about the true nature of entrepreneurship.

\section{Theoretical background}

\subsection{Cultural and regional dimensions of entrepreneurship}

There is increasing recognition in the entrepreneurship literature that various aspects of the contextual environment in which entrepreneurship takes place may have a huge impact on entrepreneurial activity (Belló et al., 2018; Hundt and Sternberg, 2014). The literature describes entrepreneurial activity as a multilevel phenomenon that includes spatial dimensions (national, regional and local environments) (e.g. Berger and Kuckertz, 2016; Valliere, 2017), social dimensions (micro-level of family, friends and all kinds of networks) (e.g. Belló et al., 2018) and the time dimension (Hundt and Sternberg, 2014). This paper focuses particularly on the spatial dimension of entrepreneurial activity, and more precisely, on the cultural and regional environment of entrepreneurial endeavours. As the following paragraphs outline, empirical findings on the relevance of cultural and regional contextual factors as well as the German particularities with regard to failure attitudes and regional differences linked to the geographical extension of the country provide grounds for this research design.

2.1.1 Cultural dimension of entrepreneurship. Cultural aspects are a major factor in shaping the environment in which an entrepreneurial activity takes place (Freytag and Thurik, 2007). The impact of cultural factors on the level of entrepreneurial activity has attracted a great deal of research attention (Cardon et al., 2011; Grichnik, 2008; Ruda et al., 2012). Scholars have used cultural constructs from the work of Hofstede (1980) and Inglehart (1997) to predict proxies for entrepreneurship, such as levels of self-employment or innovative activity, while also considering the cultural traits, such as uncertainty avoidance, that are expected to influence attitudes to certain outcomes, such as failure (Shane, 1993). According to Hofstede (1983, p. 76), culture is "the collective programming of the mind that distinguishes the members of one group or category of people from another". This so-called collective programming usually happens early in life (Hofstede, 1980) and leads to behavioural patterns, which ultimately set the cultural context (Freytag and Thurik, 2007; Hofstede, 1980; Mueller and Thomas, 2001).

Following the definition of culture proposed by Hofstede (1983), an entrepreneurial culture or a culture of entrepreneurship can be seen as an informal institution that unites norms, values and codes of conduct (Baumol, 1996; North, 1990). Furthermore, an entrepreneurial culture is characterised by a high level of social acceptance and approval of entrepreneurship (Kibler et al., 2014). Hence, entrepreneurial activity varies across countries due to different cultural values and beliefs, with some cultures being more closely aligned with entrepreneurship than others (e.g. Fernández-Serrano et al., 2018; Mueller and Thomas, 2001; Yan and Guan, 2019).

Empirical research shows that informal institutions are difficult to change, and that any change that can be triggered will be slow (North, 1990; Williamson, 2000) - unless the citizen 
IJEBR

26,8

is isolated from his or her culture (Hofstede, 1983). The same applies to cultural programmes (Hofstede, 1983); however, formal institutions (e.g. property rights), governance structures and resource allocation change far more frequently within a certain context and can be viewed as embedded in the informal institutional framework (Freytag and Thurik, 2007). Welter (2007) suggested that formal institutions can be understood as institutions that create opportunity fields for entrepreneurial activity, whereas informal institutions define the opportunity perceptions of a society and its members.

2.1.2 Regional dimension of entrepreneurship. A number of empirical studies show that both the national and regional environments can influence entrepreneurial activity (e.g. Hundt and Sternberg, 2014; Röhl, 2019). Hence, an entrepreneurial culture can vary significantly between regions (Hundt and Sternberg, 2014; Röhl, 2019; Sternberg and Rocha, 2007) within a country, regardless of whether uniform formal institutions exist nationally. This also applies to the entrepreneurial activity within the regions, which can exemplify persistent differences over time (e.g. Andersson and Koster, 2011; Armington and Acs, 2002; Audretsch and Fritsch, 1994; Bosma et al., 2008; Fritsch and Falck, 2007; Fritsch and Mueller, 2008; Fritsch and Wyrwich, 2017; Johnson and Parker, 1996). Hence, entrepreneurship as such is regarded as a regional event in the literature (Feldman, 2001; Stam, 2007; Wyrwich et al., 2016), where the entrepreneurial activity arises from the surrounding regional environment (e.g. Audretsch et al., 2012; Pierre-André, 2019; Weiss et al., 2019).

Research on the regional dimensions of entrepreneurship has attempted to demonstrate the important role entrepreneurial activity plays in the development of a region within a country. As the traditional focus of entrepreneurship research lies on the individual (Fritsch and Mueller, 2004; Kibler et al., 2014; Mueller et al., 2008; Van Stel and Storey, 2004), research at the regional level also attempts to identify regional characteristics that influence entrepreneurial activity at the individual level (Armington and Acs, 2002; Fritsch and Falck, 2007; Kibler et al., 2014; Reynolds et al., 1994; Röhl, 2019). Alongside work on demographic, structural and economic aspects of regions, researchers have also investigated how the regional culture determines the entrepreneurial activity within the region (Aoyama, 2009; Davidsson and Wiklund, 1997; Fritsch and Wyrwich, 2014; Kibler et al., 2014; Weiss et al., 2019). Furthermore, a small but growing number of studies aggregate data at the regional level with individual-level data to point to the relevance of regional factors in explaining entrepreneurial attitudes, entrepreneurial intentions and engagement in new venture creation (e.g. Bergmann and Sternberg, 2007; Mueller, 2006; Tamásy, 2006; Wagner and Sternberg, 2004). For example, research results show that regional characteristics can influence an individual's fear of failure and forestall entrepreneurial activity (e.g. Bergmann, 2005).

Audretsch and Keilbach (2007, p. 354) referred to a region's "capacity to generate entrepreneurial behaviour in general, and the start-up of new firms in particular" as the region's entrepreneurship capital. The special feature of the definition of entrepreneurship capital is that it comprises not only the set of economic opportunities and human capital that is beneficial for entrepreneurship and entrepreneurial activity but also institutions, value sets, (cultural) traditions and habits (Audretsch and Keilbach, 2007). Accordingly, regional perceptions of entrepreneurs and the attitude of the local population to risk, business failure or economic success are regional cultural characteristics potentially relevant to entrepreneurship and entrepreneurial activity (Stuetzer et al., 2014). Hence, entrepreneurship capital is considered a locally bounded phenomenon that is driven by local culture and should, therefore, be measured within a city or region (Audretsch and Keilbach, 2007). Furthermore, Stuetzer et al. (2014) assumed that potential founders of new ventures have a feeling for a region's entrepreneurship capital, meaning that if they perceive entrepreneurship capital to be at a high level, they will be more likely to establish a new venture. 


\subsection{Entrepreneurship in Germany}

The present study focuses specifically on entrepreneurship in Germany. The German economy is known for being very strong and stable. After the financial crisis of 2008-2009, Germany recovered quickly, showing that the German economy is a leading economy in Europe (Audretsch et al., 2015; Dustmann et al., 2014; Kalden et al., 2017). In addition, compared with other (innovation-driven) economies outside of Europe, such as the USA, Germany shows its strength and competitiveness (Kalden et al., 2017), which might have prepared it well for its recovery from the COVID-19 crisis as well.

The comparable economic growth and development rates of Germany and the USA create expectations that they will demonstrate similar levels of entrepreneurial activity. However, despite Germany's strong and stable economy, the number of new ventures being founded in Germany have been falling for several years compared to in the USA (Kalden et al., 2017; $\mathrm{KfW}$,2018). Recent figures on the total early-stage entrepreneurial activity (TEA) in Germany reveal an average of $7.6 \%$ compared to $17.42 \%$ in the USA (GEM, 2020; Sternberg et al., 2020). Furthermore, recent research results show that the number of companies founded in Germany is continuously falling (KfW, 2018), putting Germany among the countries with the lowest rates of business start-ups worldwide (Sternberg et al., 2020). However, Germany needs founders of new businesses to strengthen the competitiveness of the German economy and maintain a high level of innovativeness (Tamásy, 2006).

The low level of entrepreneurial activity in Germany might be due to the widespread fear of failure in Germany, which is reported to remain relatively high and stable over time compared with international rates. Fear of failure and potentially the stigma of failure would deter $36 \%$ of Germans from starting a business (KfW, 2018).

Germany's weakness regarding the founding of new ventures might also have a cultural and/or regional dimension (Kuckertz et al., 2015; Röhl, 2016). Although Hofstede (1983) did not explicitly focus on the relationship between culture and entrepreneurial activity, his work is helpful in determining the key aspects of a culture that affect entrepreneurial activity within a country (Mueller and Thomas, 2001). According to Hofstede (1983), the German culture is characterised by a strong uncertainty avoidance. Therefore, when it comes to entrepreneurial activity, Germans are more risk-averse, have a rather negative attitude to new ventures and are afraid of failure (Sternberg et al., 2004); hence, they show failure reservations, which consequently trigger negative perceptions towards the idea of founding a new company (Röhl, 2016). Furthermore, even in a country like Germany with comparatively low interregional economic disparities (Hundt and Sternberg, 2014), the regions are not at all homogenous (Hundt and Sternberg, 2014; KfW, 2018), meaning that the regional context also plays a crucial part regarding entrepreneurial activity in Germany. This is also evident from the differences of the level of entrepreneurship in East and West Germany (a differentiation based on German history). Even almost three decades after the reunification of the mature market economy (West Germany) and the former socialist economy (East Germany), East German regions regularly feature at the bottom of entrepreneurial activity rankings (KfW, 2018). This trend reflects the fact that entrepreneurship remains less accepted in the eastern part than in the western part of Germany, which can be traced back to the socialist legacy of East Germany (Wyrwich et al., 2016). Against the background of the theoretical arguments outlined above, it is hypothesised:

H1. The perception of entrepreneurship and entrepreneurial activity varies within a country and/or cultural context.

\subsection{Entrepreneurial failure and the misperception of entrepreneurship in Germany}

Entrepreneurship naturally involves accepting risks, and because risk indicates not only growth potential but also the potential to lose something, starting a promising new venture is 
IJEBR

26,8 closely tied to potential entrepreneurial failure. Facing the prospect of failure is an inevitable and significant outcome of being involved in the start-up environment (Cope et al., 2004). Although businesses begin with the expectation that they will survive (Shepherd et al., 2000), research shows that a significant proportion of new ventures fail (Headd, 2003; Wiklund et al., 2010). Accordingly, entrepreneurial failure is an important phenomenon in entrepreneurship (Cardon et al., 2011) and one that is increasingly recognised given its implications for entrepreneurs and their role in society (Singh et al., 2015).

Failure is often viewed as something to be avoided because it can be "painful and costly, can generate vicious cycles of discouragement and decline, and can obviously be mismanaged" (McGrath, 1999, p. 16). Entrepreneurial failure may also be an emotional and traumatic experience (Cope, 2011; Shepherd, 2003) because an entrepreneur's identity is closely interwoven with his or her venture (Cardon et al., 2005). However, failure may also be functional, in that it can provide opportunities from which entrepreneurs can learn (Corbett et al., 2007; Shepherd, 2003; Walsh and Cunningham, 2017; Lattacher and Wdowiak, 2020) and can, thus, prompt entrepreneurs to improve their entrepreneurial competence (EspinosaBenavides and Díaz, 2019), which can have an impact on further economic and business development (McGrath, 1999).

The concept of failure itself is hard to define (Fredland and Morris, 1976; Scott and Lewis, 1984) because it has been specified and operationalised in many different ways. However, providing a clear definition of failure is important because it enables comparisons across studies and influences the nature of outcomes and processes that researchers observe. This paper follows the definition of business failure suggested by Ucbasaran et al. (2013, p. 175) as "the cessation of involvement in a venture because it has not met a minimum threshold for economic viability as stipulated by the entrepreneur". The definition is comprehensive and explores failure from the entrepreneurship perspective, meaning that it relies on the entrepreneur's expectation of economic viability to dictate if the definition is met (Walsh and Cunningham, 2016). This definition also illustrates that venture failure is a defining moment in the life of any entrepreneur (Mandl et al., 2016).

The literature on entrepreneurial failure shows that differences exist in the way individuals and societies in different geographical regions experience and tolerate entrepreneurial failure (Cardon et al., 2011). These differences have implications for the level of entrepreneurial activity that occurs within a country or region and influences the acceptability of entrepreneurship as a viable career path (Cardon et al., 2011; Davidsson, 1995; Landier, 2005).

The willingness to take on manageable risks when starting a venture (Koe, 2016), and the uncertainty and acceptance of the possibility of entrepreneurial failure (Shepherd and Patzelt, 2017) with all its consequences (Cassar, 2007; Ruda et al., 2012) being central to entrepreneurship contrast with the cultural background of German society, leading most Germans to avoid risky endeavours (Hofstede, 1983). The uncertainty associated with founding a new company, as well as potential entrepreneurial failure, is perceived negatively by many Germans (Röhl, 2016; Sternberg et al., 2004). Moreover, entrepreneurs with a failure in their history often face negative attitudes (Wagner, 2002; Wyrwich et al., 2016). As a consequence, many people in Germany appear to be fearful of the obstacles and risks associated with founding a new venture even before they have assessed the pros and cons of self-employment in detail (Röhl, 2016). Consequently, a certain misperception of the nature of entrepreneurship in Germany is assumed. It seems that there is a lack of comprehension among German society of what entrepreneurial activity involves (Cope et al., 2004; Panwar et al., 2014). Germans do not seem to perceive entrepreneurship as a process that requires entrepreneurs to assume risk and one that inherently carries the possibility of failure (Koe, 2016). Given that Germans' perceptions of the nature of entrepreneurship seems mistaken and/or distorted, the following hypothesis is posited: 
H2. The stronger the individual's misperception of the nature of entrepreneurship, the stronger the individual's failure reservations.
Entrepreneurial failure

\section{Methodology}

For the present study, 2,027 representatively selected German residents aged between 18 and 67 years were surveyed online with the help of a commercial service provider. This service provider allows to potentially access 1.3 million panellists in Europe, with an emphasis on the German market. The panel has been used for market and academic research successfully over the past two decades. Hence, it became possible to invite survey participants corresponding to the German average working population according to gender, age and origin (at federal state level). While absolute representativeness for the data cannot be claimed, it is nonetheless approximated as closely as possible through this particular means of data collection. The resulting sample is slightly older than what is known about the German working population ( 44 vs 48 years in the sample) and slightly more female (51 vs $53 \%$ in the sample) (Destatis, 2020).

Three attitudinal items on business failure from the German version of Eurobarometer (2002) were used against the background of the following framing: "Now we are interested in how you see entrepreneurs who have failed with their business". Participants were asked to respond on a seven-point Likert-scale $(1=$ strongly disagree; $7=$ strongly agree). The dependent variable failure reservations reflects the perceptions of entrepreneurship and entrepreneurial activity in terms of failure reservations while capturing the attitudes towards failed entrepreneurs. The variable is measured using two items adopted from the Eurobarometer (2002) study: "I would be less inclined to order goods from someone who has already failed in business" and "I would never invest money in a business managed by somebody who has already failed in the past" (Cronbach's alpha: 0.67).

The independent variable misperception of entrepreneurship captures an individual's tolerance of risk in the light of failure. Hence, the variable addresses the central elements of the nature of entrepreneurship such as uncertainty, risk and the possibility of entrepreneurial failure on the societal level, with the single item, "One should not start a business if there is a risk it might fail". This item is also used as a risk tolerance measure in studies by both Grilo and Irigoyen (2006) and Kautonen et al. (2014). The labelling of the independent variable as misperception of entrepreneurship in the present study can be attributed to the assumption that entrepreneurship and the risk of failure go hand in hand. Hence, if an individual agrees to the statement "One should not start a business if there is a risk it might fail", he/she seems to not understand what entrepreneurship is about. Hence, the individual seems to have a misperception of entrepreneurship.

Furthermore, as controls, variations by individual respondent characteristics such as age, education, employment status, gender, income and whether the respondent personally knows a failed entrepreneur were considered. With regard to the targeted investigation of regional differences regarding the response behaviour of the participants, the German federal states with North-Rhine Westphalia as the base region, which is the federal state with the highest population, were considered as well. To test the proposed hypotheses, a multivariate regression analysis in four steps was run.

\section{Results}

Table 1 presents the descriptive statistics and correlations among the study variables with the exception of income and federal state (the correlations between all study variables are available upon request). The final research sample comprised 962 men (47.5\%) and 1,065 women $(52.5 \%)$ aged between 18 and $69\left(M_{\text {age }}=48.68, \mathrm{SD}_{\text {age }}=11.92\right)$. Most participants 
IJEBR

26,8

1872

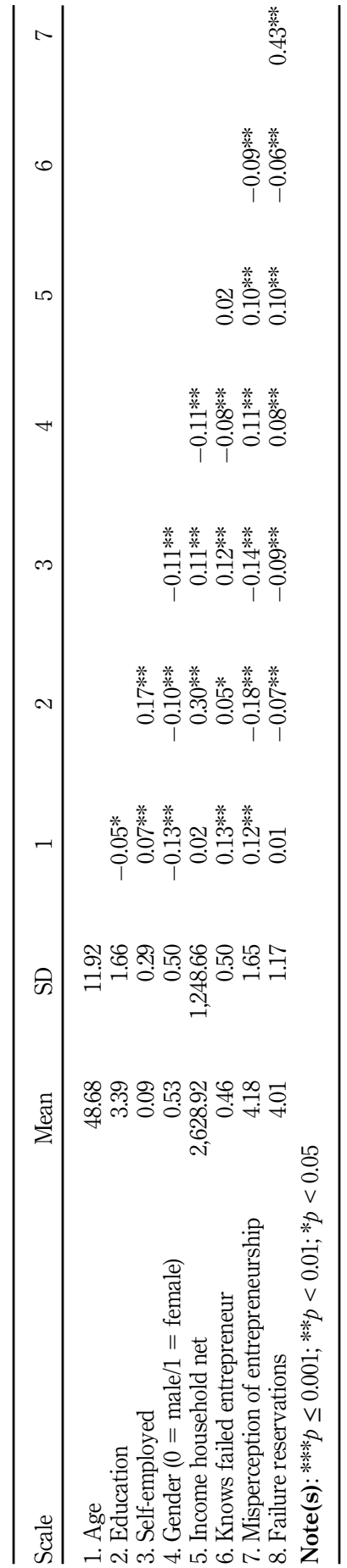

Table 1.

Descriptive statistics and correlations between the study variables (income and federal states omitted) 
$(60.5 \%)$ had a minimal level of professional education, meaning that they have at least finished a training programme or graduated from a professional school. Almost half of the respondents (46.4\%) claimed to know a failed entrepreneur and 188 participants $(9.3 \%)$ were self-employed. Correlations are not excessively high, and variance inflation factors are all well below the usual threshold of 10 (Neter et al., 1996), which suggests multicollinearity is not an issue with these data. Equally, potential common method variance seems to be negligible, as the research team took a priori procedural measures (Podsakoff et al., 2003) to minimise common method variance during data collection (e.g. securing anonymity for respondents and shuffling scale formats and types of questions). Given that the data structure of the sample does not allow to employ more elaborate statistical procedures such as, for instance, the use of marker variables or confirmatory factor analysis (CFA), Harman's classic singlefactor test (Harman, 1967) was nonetheless applied to the study's variables, which resulted in a multi-factorial solution, with the first factor only accounting for a fraction of the variance. This is in line with assessments of the field suggesting common method bias is generally an issue of lesser concern in business and management research (Fuller et al., 2014).

Table 2 presents the results of the multivariate regression analysis. Model 1 in Table 2 is one of the control models and contains all control variables, except income, which is included in the second control model, Model 2. Model 3 is the regional model that contains all controls, including the federal states. Model 4 incorporates the independent variable misperception of entrepreneurship and is therefore labelled the theoretical model. The model summary shows the explanatory power of the independent variables. The adjusted $R^{2}(=0.193)$ indicates that the independent variable explains approximately $19.3 \%$ of observed variation in the dependent variable of the theoretical model.

The results support the assumption that the perception of the nature of entrepreneurship in terms of failure reservations varies within a certain country and/or cultural context, and that regional differences must also be considered (supporting H1). For example, in the regional model, German respondents living in the city-state Bremen $(\beta=-0.05, p<0.05)$, or in the states Rhineland-Palatinate $(\beta=-0.06, p<0.05)$ or Saxony-Anhalt $(\beta=-0.04$, $p<0.10$ ), show significantly lower failure reservations than Germans living in the city-state of $\operatorname{Berlin}(\beta=0.05, p<0.05)$. Prior research illustrates that the opinion on entrepreneurs can be negatively affected by the potential socialist heritage of a particular country (Adam-Müller et al., 2015). Germany might be special in this regard, as its eastern parts exhibit such a socialist heritage, while its western parts do not. Inspecting the federal states in Table 2, however, reveals no clear pattern regarding differences between East and West German federal states. Moreover, substituting the federal states with a dummy variable accounting for whether a survey respondent lives in the eastern or western parts of Germany returns insignificant results (available from the authors upon request), suggesting socialist heritage does not play a role in explaining regionally different failure reservations in the sample.

Notably, knowing a failed entrepreneur reduces failure reservations significantly in the first three models but becomes insignificant once the misperception of entrepreneurship variable is entered into the equation. Furthermore, the multiple regression analysis results show that the misperception of entrepreneurship has a significant positive effect on the dependent variable failure reservations. Accordingly, the results indicate that the stronger a German individual's misperception of the nature of entrepreneurship, the stronger the actual reservations of the German individual towards failed entrepreneurs $(\beta=0.42, p<0.001)$, thus supporting $\mathrm{H} 2$.

Overall, the results support the assumption that economic conditions of a country or region alone do not influence the level of entrepreneurial activity within that country or region. The societal and cultural context in which entrepreneurship takes place might also have an impact on the entrepreneurial activity and the perception of entrepreneurship (e.g. Grichnik, 2008; Cardon et al., 2011; Ruda et al., 2012).
Entrepreneurial failure

1873 


\section{IJEBR \\ 26,8}

\begin{tabular}{|c|c|c|c|c|}
\hline & $\begin{array}{c}\text { Control model } 1 \\
\text { Standardised } \\
\text { coefficient }^{\mathrm{a}} \text { (SE) }\end{array}$ & $\begin{array}{c}\text { Control model } 2 \\
\text { Standardised } \\
\text { coefficient }^{\mathrm{a}, \mathrm{b}}(\mathrm{SE})\end{array}$ & $\begin{array}{l}\text { Regional model } \\
\text { Standardised } \\
\text { coefficient, b, c (SE) }\end{array}$ & 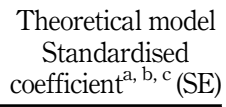 \\
\hline (CONSTANT) & $3.95(0.13)^{* * * *}$ & $3.95(0.15)^{* * * *}$ & $3.98(0.16)^{* * * *}$ & $3.00(0.15)^{* * * *}$ \\
\hline \multicolumn{5}{|l|}{ Controls } \\
\hline Age & $0.03(0.00)$ & $0.03(0.00)$ & $0.02(0.00)$ & $-0.03(0.00) \dagger$ \\
\hline Education & $-0.04(0.02)^{*}$ & $-0.02(0.02)$ & $-0.03(0.02)$ & $0.03(0.02)$ \\
\hline Self-employed & $-0.07(0.09)^{* * *}$ & $-0.06(0.09)^{* * *}$ & $-0.06(0.09)^{* * *}$ & $-0.01(0.08)$ \\
\hline Gender & $0.07(0.05)^{* * *}$ & $0.06(0.05)^{* * *}$ & $0.06(0.05)^{* * *}$ & $0.02(0.05)$ \\
\hline $\begin{array}{l}\text { Knows failed } \\
\text { entrepreneur }\end{array}$ & $-0.05(0.05)^{*}$ & $-0.05(0.05)^{*}$ & $-0.05(0.05)^{*}$ & $-0.02(0.05)$ \\
\hline Income $<€ 1,000$ & & $-0.01(0.11)$ & $-0.01(0.11)$ & $-0.01(0.10)$ \\
\hline \multicolumn{5}{|l|}{$€ 2,000$} \\
\hline $\begin{array}{l}\text { Income } € 2,000- \\
€ 3,000\end{array}$ & & $-0.01(0.09)$ & $-0.02(0.08)$ & $-0.02(0.08)$ \\
\hline $\begin{array}{l}\text { Income } € 3,000- \\
€ 4,000\end{array}$ & & $-0.03(0.10)$ & $-0.03(0.10)$ & $-0.03(0.09)$ \\
\hline $\begin{array}{l}\text { Income } € 4,000- \\
€ 5,000\end{array}$ & & $-0.02(0.11)$ & $-0.02(0.11)$ & $-0.02(0.10)$ \\
\hline Income $>€ 5,000$ & & $-0.11(0.13)^{* * *}$ & $-0.11(0.13)^{* * *}$ & $-0.09(0.12)^{* * *}$ \\
\hline Berlin & & & $0.05(0.13)^{*}$ & $0.04(0.12) \dagger$ \\
\hline \multirow{2}{*}{\multicolumn{5}{|c|}{ Wuerttemberg }} \\
\hline & & & & \\
\hline Bavaria & & & $0.02(0.09)$ & $0.02(0.08)$ \\
\hline Brandenburg & & & $-0.00(0.15)$ & $0.00(0.14)$ \\
\hline Bremen & & & $-0.05(0.29)^{*}$ & $-0.04(0.27)^{*}$ \\
\hline Hamburg & & & $0.01(0.18)$ & $-0.00(0.16)$ \\
\hline Hesse & & & $-0.01(0.11)$ & $-0.01(0.10)$ \\
\hline Mecklenburg & & & $0.04(0.19)$ & $0.02(0.18)$ \\
\hline \multicolumn{5}{|l|}{ Western Pomerania } \\
\hline Lower Saxony & & & $-0.00(0.10)$ & $-0.01(0.09)$ \\
\hline Rhineland- & & & $-0.06(0.13)^{*}$ & $-0.04(0.12)^{*}$ \\
\hline \multicolumn{5}{|l|}{ Palatinate } \\
\hline Saarland & & & $-0.00(0.24)$ & $0.00(0.22)$ \\
\hline Saxony & & & $0.04(0.13) \dagger$ & $0.03(0.12)$ \\
\hline Saxony-Anhalt & & & $-0.04(0.16) \dagger$ & $-0.05(0.15) *$ \\
\hline Schleswig-Holstein & & & $0.01(0.15)$ & $-0.01(0.14)$ \\
\hline Thuringia & & & $0.01(0.16)$ & $-0.01(0.15)$ \\
\hline \multicolumn{5}{|l|}{ Independent variable } \\
\hline $\begin{array}{l}\text { Misperception of } \\
\text { entrepreneurship }\end{array}$ & & & & $0.42(0.02)^{* * *}$ \\
\hline \multicolumn{5}{|l|}{ Model summary } \\
\hline$R$ & 0.13 & 0.17 & 0.21 & 0.45 \\
\hline$R^{2}$ & 0.02 & 0.03 & 0.04 & 0.20 \\
\hline Adjusted $R^{2}$ & 0.02 & 0.02 & 0.03 & 0.19 \\
\hline $\begin{array}{l}\text { Standard error of the } \\
\text { estimate } \\
N=2,027\end{array}$ & 1.16 & 1.15 & 1.15 & 1.05 \\
\hline \multicolumn{5}{|c|}{$\begin{array}{l}\text { Note(s): } * * * p \leq 0.001 ; * * p \leq 0.01 ; * p \leq 0.05 ; \dagger p \leq 0.1 \\
\text { aDependent variable: failure reservations } \\
\text { bNo income declared as base } \\
{ }^{c} \text { North-Rhine Westphalia as base region }\end{array}$} \\
\hline
\end{tabular}




\section{Discussion}

The present study adds to the emerging literature on entrepreneurial failure. By explaining that differences exist in the way individuals and societies of different geographic regions perceive and tolerate entrepreneurial failure, which influences the acceptability of entrepreneurship as a viable career path, entrepreneurial failure is embedded in a cultural and spatial context. While focusing on the German population, the evaluator perspective on entrepreneurial failure (Shepherd and Patzelt, 2017) is advanced, and insights into how entrepreneurial failure is perceived by the overall population in an innovation-driven economy are generated. Understanding the German case can, thus, aid the understanding and derivation of political measures for many other western countries, most of which also show low levels of entrepreneurial activity (Brännback and Carsrud, 2008).

To date, scholars have argued that failure reservations play an important role in explaining national differences at the level of entrepreneurial activity owing to possible negative spillover effects that undermine the willingness of individuals to enter into entrepreneurship (Armour and Cumming, 2008; Politis and Gabrielsson, 2009), or to start a new venture following a business failure (Armour and Cumming, 2008). However, fewer startups imply less economic progress for a region and for a country (McKeon et al., 2004; Warren, 2004). Furthermore, failure can create substantial psychological, economic and social costs for entrepreneurs (Cardon et al., 2011; Ucbasaran et al., 2013; Shepherd and Patzelt, 2017), which can impede learning from failure (Cope and Watts, 2000; Singh et al., 2007). Consequently, an improved perception of entrepreneurship, greater tolerance of failed entrepreneurs and a reduction in entrepreneurial failure reservations could support emotional recovery and foster learning from failure (Shepherd, 2003), which could in turn help entrepreneurs to build a legitimate professional image for future career actions (Elsbach, 1994, 2003; Garud et al., 2014).

Accordingly, scholars recommend that national policymakers should try to influence the societal perception of entrepreneurship and entrepreneurial failure (e.g. Dileo and García Pereiro, 2019; Simmons et al., 2014) to promote the development of an entrepreneur-friendly culture (Wagner and Sternberg, 2004; Röhl, 2016). However, such approaches may not deliver their potential for change because one of the research outcomes suggests that reservations about failed entrepreneurs - at least in the German setting - can result from serious misperceptions about entrepreneurship: most Germans do not seem to perceive entrepreneurship as a process that requires entrepreneurs to assume risk and that carries the possibility of failure (Koe, 2016). Moreover, it seems that being familiar with failed entrepreneurs does not heal reservations towards them if misperceptions about the nature of entrepreneurship prevail. The results also show that the perception of entrepreneurship and entrepreneurial activity in terms of failure reservations vary within German states, with Bremen, Saxony-Anhalt and Rhineland-Palatinate showing weaker failure reservations. The current research findings suggest that policymakers should not merely invest in campaigns aimed at creating a culture of second chances - because that approach frequently does not translate into reducing failure reservations - but they should invest in enhancing general education about the realities of entrepreneurship. Doing so could strengthen underdeveloped entrepreneurial cultures and encourage citizens to engage in entrepreneurship (e.g. Meccheri and Pelloni, 2006). Table 3 translates the findings into actionable measures at the national and regional levels for policymakers and educators against the background of two predominant challenges: first, to enhance a country's entrepreneurial culture and, second, to educate the true nature of entrepreneurship.

In recent years, there has been a substantial increase in the interest on entrepreneurship on the part of public policymakers (Drakopoulou Dodd et al., 2013). This interest spans all relevant spatial levels of government activities, such as the supranational level (global/ continental) (European Union (EU) programmes supporting entrepreneurship), the national
Entrepreneurial failure

1875 


\section{IJEBR 26,8}

Challenges Implications for policymakers

(1) Roll out nationwide and regional entrepreneurship support policies (e.g. entrepreneurship-friendly bankruptcy laws, facilitated administrative processes)

(2) Foster entrepreneurship support services (e.g. government provision of information, incubators, training and funding)

(3) Promote entrepreneurship initiatives (e.g. Entrepreneurship Weeks) and competitions (e.g. founder prizes)

(4) Promote media stories about (failed) entrepreneurs (e.g. TV formats like Dragon's Den)

(5) Support entrepreneurship events (e.g. FuckUp Nights)

Educate the true nature of entrepreneurship Individuals need to understand entrepreneurship as a process that requires entrepreneurs to assume risk and that carries the possibility of failure
(1) Include entrepreneurship education in the curriculum of schools and universities

(2) Strengthen entrepreneurship education in schools and universities (e.g. JUNIOR programme)

(3) Support selected entrepreneurship initiatives at schools (e.g. student-run companies) and universities (e.g. business simulations)
Implications for educators

(1) Transfer of entrepreneurship education to the general public, e.g. by educators talking about entrepreneurship in the media, entrepreneurship workshops (e.g. self-initiative training) open to the public, events in the sense of $\mathrm{Ted}$ Talks on entrepreneurship

(2) Promote the creation of entrepreneurial universities

(1) Introduce entrepreneurship courses and business simulation games into classes

(2) Support the creation of student-run companies

(3) Present realistic and diverse entrepreneurial role models in class

(4) Foster/teach different forms of entrepreneurship following from entrepreneurial culture such as sustainable or social entrepreneurship
Table 3. for policymakers and educators level (nationwide entrepreneurship support policies like entrepreneurship-friendly bankruptcy laws and services or initiatives such as Entrepreneurship Weeks, as well as competitions like founder prizes), the regional level (entrepreneurship support services, like incubators) and even the local level (entrepreneurship programmes for selected cities).

Strengthening entrepreneurship education in schools and universities through the inclusion of entrepreneurship education into the curricula is also hugely important (Piegeler and Röhl, 2015). While most entrepreneurship education currently takes place with a reliance on real-world and hands-on experience, the COVID-19 crisis and its aftermath have resulted in the discussion of how online entrepreneurship education needs to be designed to achieve a similar experience (Liguori and Winkler, 2020). The development of more appropriate online formats to provide entrepreneurship education might also lead to a greater number of students being educated in entrepreneurship, which would aid a more realistic perception of entrepreneurship. Furthermore, projects such as the German JUNIOR programme, which aims to establish entrepreneurship in schools by teaching entrepreneurial thinking and familiarising pupils with the idea and nature of entrepreneurship at an early stage (JUNIOR, 2017), should be given increased support. At the university level, entrepreneurial education aims to promote a better understanding of the nature of entrepreneurship among students 
from all faculties. Initiatives include action-oriented formats where students learn to apply theory in practice while experiencing how to turn venture ideas into reality with the support of passionate fellow students and mentors (Middleton et al., 2020).

Entrepreneurship education is not just about teaching someone to run a business; it is also about developing an improved widespread understanding of entrepreneurship with the aim of reducing misperceptions and reservations about the topic. However, while talking about entrepreneurship and entrepreneurs, educators should pay greater attention to the effect the presentation of entrepreneurial role models might have on students. Attempting to reproduce stereotypical entrepreneurs (such as the heroic Richard Branson) in class (Neck and Greene, 2011) might be not fruitful and does not contribute to the understanding of entrepreneurship. Instead, entrepreneurial role models with whom students can identify and who represent the range of founder types promise to be more influential on students. Educators should also pay attention to teach pupils and students about different forms of entrepreneurship, such as sustainable or social entrepreneurship - depending on the entrepreneurial culture within a country or region.

To make entrepreneurship education more part of a public discourse, entrepreneurship education formats that address the general public are also necessary. These include, for example, educators talking about entrepreneurship in the media, entrepreneurship workshops (e.g. self-initiative training) open to the public or events in the sense of Ted Talks on entrepreneurship and latest findings in entrepreneurship research. Furthermore, educators should promote the creation of entrepreneurial universities to illustrate that applying and/or living an entrepreneurial culture does not necessarily mean to found a business.

Although entrepreneurial education can both attract people to and deter them from entrepreneurial activity, students and societies benefit from having a solid entrepreneurial education that provides citizens with entrepreneurial knowledge alongside skills useful for employment (Kuckertz, 2013). However, schools and universities can usually only introduce long-term approaches to entrepreneurial education. Short-term approaches can be seen in the promotion of media stories about (failed) entrepreneurs, TV shows like Dragons' Den or Shark Tank, or events such as FuckUp Nights where professional failure stories are shared and discussed.

Policy and educational initiatives might be ineffective in regions with a low level of social approval of entrepreneurship where the social norms and values are at odds with entrepreneurship. Furthermore, as the sources of an entrepreneurship culture are rooted in the economic history of a country, attempts to stimulate the establishment of a regional entrepreneurship culture will need to reach far back into a country's past (Fritsch and Wyrwich, 2017). Encouraging entrepreneurial activity in regions that lack an adequate entrepreneurial culture might be more effective when preceded by positive steps to foster a positive entrepreneurial climate (Fritsch and Wyrwich, 2017).

As a whole, the research results should be interpreted as a clear argument against general, uniform, "one-size-fits-all" policies and initiatives to advance entrepreneurial activity in countries, regions, cities and all times (cf. Díez-Martín et al., 2016). National and supranational efforts to stimulate entrepreneurship may inherently be doomed to fail or at least to disappoint. As entrepreneurship is crucial for growth and employment generation, local and regional policies should be prioritised (Audretsch and Keilbach, 2007), and policymakers and educators should expressly consider the space- and time-specific context while educating people about the realities of entrepreneurship and developing entrepreneurship policies (Hundt and Sternberg, 2014).

Irrespective of its contributions, the present study is not without limitations; however, those limitations illuminate promising avenues for future research. Entrepreneurship is a multifaceted phenomenon, as is entrepreneurial failure. While generating conclusions about entrepreneurial failure reservations, no distinctions could be derived between, for instance, a 
IJEBR

26,8

1878 failed technology start-up that was unable to bring a product to market and a third-generation family business that went bankrupt. Both these and other modes of failure might dramatically affect the perceptions held by the general population and thus warrant further investigation. Furthermore, research suggests a strong association between national and regional cultural values and entrepreneurship beliefs (Stenholm et al., 2013; Kibler and Kautonen, 2016). In this regard, it must be assumed that the results of a study based on German culture are - although trend-setting for many other western countries with low levels of entrepreneurial activity - not fully generalisable to other cultural contexts where failure and entrepreneurship might be perceived differently. Therefore, international studies comparing the perception of entrepreneurship and failure reservations in different spatial settings might paint an even clearer picture of where political measures could be effective. Third, this paper uses attitudinal items that might fail to capture some important nuances of business failure. The final model's $R^{2}$ values suggest that a substantial amount of the variance in the dependent variable could be explained. However, there is room for additional explanations that might be worth including; for instance, more concepts accounting for psychological traits of evaluators. Furthermore, recent research suggests that people perceive business failure differently depending on the cause of failure (Kibler et al., 2017). Defining failure in a positive light or linking failure to external factors beyond the control of the failed entrepreneur could yield more positive legitimacy judgements and higher levels of social approval (Shepherd and Haynie, 2011). Also, the online data collection facilitated by a service provider might be a typical example of digital technologies excluding entire groups due to their lack of technical equipment or skills (Berger et al., in press) from the sample. Taking this into account in future studies while adapting the items used here might produce a more detailed picture of the phenomenon.

\section{Conclusion}

The current study demonstrates that the perception of entrepreneurship and entrepreneurial activity can vary within a certain country and/or cultural context. Moreover, regional differences within a country and/or cultural context must also be considered while determining the perception of entrepreneurship and its impact on failure reservations. While referring to the German case, specifically entrepreneurship in Germany and Germans' perceptions of entrepreneurship, it was possible to show how misperceptions of the nature of entrepreneurship affect entrepreneurial failure reservations in Germany. The principal research findings imply that the stronger the individual misperceptions of the nature of entrepreneurship, the worse the reservations about failed entrepreneurs. Furthermore, the results demonstrate that regional differences exist in Germany that vary with the degree of failure reservations. With reference to the research outcome, the development of effective policy initiatives tailored to region-specific needs to boost entrepreneurial activity within a country and its regions are needed. Moreover, the discussion emphasises that talking positively about entrepreneurial failure will not suffice to remove failure reservations, particularly in Germany. Similarly, it is not enough merely to invest in campaigns aimed at creating a failure-friendly culture in Germany. Instead, better education about the realities of entrepreneurship is needed, and education should take regional differences in the perceptions of entrepreneurship and failure reservations into account.

\section{References}

Adam-Müller, A., Andres, R., Block, J. and Fisch, C. (2015), "Socialist heritage and the opinion on entrepreneurs", Die Betriebswirtschaft, Vol. 74 No. 4, pp. 211-232.

Andersson, M. and Koster, S. (2011), "Sources of persistence in regional start-up rates: evidence from Sweden”, Journal of Economic Geography, Vol. 11 No. 1, pp. 179-201. 
Aoyama, Y. (2009), "Entrepreneurship and regional culture: the case of Hamamatsu and Kyoto, Japan”, Regional Studies, Vol. 43 No. 3, pp. 495-512.

Armington, C. and Acs, Z.J. (2002), "The determinants of regional variation in new firm formation", Regional Studies, Vol. 36 No. 1, pp. 33-45.

Armour, J. and Cumming, D.J. (2008), "Bankruptcy law and entrepreneurship", American Law and Economics Review, Vol. 10 No. 2, pp. 303-350.

Audretsch, D.B. and Fritsch, M. (1994), “The geography of firm births in Germany”, Regional Studies, Vol. 28 No. 4, pp. 359-365.

Audretsch, D.B. and Keilbach, M. (2007), "The localisation of entrepreneurship capital: evidence from Germany", Papers in Regional Science, Vol. 86 No. 3, pp. 351-365.

Audretsch, D.B., Falck, O., Feldman, M.P. and Heblich, S. (2012), "Local entrepreneurship in context", Regional Studies, Vol. 46 No. 3, pp. 379-389.

Audretsch, D.B., Lehmann, E.E. and Paleari, S. (2015), "Academic policy and entrepreneurship: a European perspective", The Journal of Technology Transfer, Vol. 40 No. 3, pp. 363-368.

Baumol, W.J. (1996), "Entrepreneurship: productive, unproductive, and destructive", Journal of Business Venturing, Vol. 11 No. 1, pp. 3-22.

Belló, B., Mattana, V. and Loi, M. (2018), "The power of peers: a new look at the impact of creativity, social context and self-efficacy on entrepreneurial intentions", International Journal of Entrepreneurial Behavior and Research, Vol. 24 No. 1, pp. 214-233.

Berger, E.S.C. and Kuckertz, A. (2016), "Female entrepreneurship in startup ecosystems worldwide", Journal of Business Research, Vol. 69 No. 11, pp. 5163-5168.

Berger, E.S.C., von Briel, F., Davidsson, P. and Kuckertz, A. (in press), "Digital or not-The future of entrepreneurship and innovation: introduction to the special issue", Journal of Business Research.

Bergmann, H. and Sternberg, R. (2007),"The changing face of entrepreneurship in Germany”, Journal of Small Business Economics, Vol. 28 Nos 2-3, pp. 205-221.

Bergmann, H. (2005),“Entrepreneurial attitudes: Wodurch werden sie determiniert und welche Rolle spielt die Region?”, Zeitschrift für Wirtschaftsgeographie, Vol. 49 Nos 3-4, pp. 185-199.

Block, J., Fisch, C. and Hirschman, M. (2020), "Solo self-employed individuals and bootstrap financing in the COVID-19 crisis", Working Paper, Faculty of Management, University of Trier, Trier, 18 May.

Bosma, N., Van Stel, A. and Suddle, K. (2008), "The geography of new firm formation: evidence from independent start-ups and new subsidiaries in The Netherlands", The International Entrepreneurship and Management Journal, Vol. 4 No. 2, pp. 129-146.

Brännback, M. and Carsrud, A. (2008), "Do they see what we see?: a critical Nordic tale about perceptions of entrepreneurial opportunities, goals and growth", Journal of Enterprising Culture, Vol. 16 No. 1, pp. 55-87.

Cardon, M.S., Zietsma, C., Saparito, P., Matherne, B.P. and Davis, C. (2005), "A tale of passion: new insights into entrepreneurship from a parenthood metaphor", Journal of Business Venturing, Vol. 20 No. 1, pp. 23-45.

Cardon, M.S., Stevens, M. and Potter, D. (2011), "Misfortunes or mistakes? Cultural sensemaking of entrepreneurial failure", Journal of Business Venturing, Vol. 26 No. 1, pp. 79-92.

Cassar, G. (2007), "Money, money, money? A longitudinal investigation of entrepreneur career reasons, growth preferences and achieved growth", Entrepreneurship and Regional Development, Vol. 19 No. 1, pp. 89-107.

Cope, J. and Watts, C. (2000), "Learning by doing: an exploration of experience, critical incidents and reflection in entrepreneurial learning", International Journal of Entrepreneurial Behavior and Research, Vol. 6 No. 3, pp. 104-124.

Cope, J., Cave, F. and Eccles, S. (2004), "Attitudes of venture capital investors towards entrepreneurs with previous business failure", Venture Capital, Vol. 6 Nos 2-3, pp. 147-172. 
IJEBR 26,8

Cope, J. (2011), "Entrepreneurial learning from failure: an interpretative phenomenological analysis", Journal of Business Venturing, Vol. 26 No. 6, pp. 604-623.

Corbett, A.C., Neck, H.M. and DeTienne, D.R. (2007), "How corporate entrepreneurs learn from fledgling innovation initiatives: cognition and the development of a termination script", Entrepreneurship: Theory and Practice, Vol. 31 No. 6, pp. 829-852.

Creditreform (2017), "Insolvenzen in Deutschland [Bankruptcies in Germany]", available at: https:// www.creditreform.de/nc/aktuelles/news-list/details/news-detail/insolvenzen-in-deutschlandjahr-2017.html (accessed 5 November 2018).

Davidsson, P. and Wiklund, J. (1997), "Values, beliefs and regional variations in new firm formation rates”, Journal of Economic Psychology, Vol. 18 Nos 2-3, pp. 179-199.

Davidsson, P. (1995), "Culture, structure and regional levels of entrepreneurship", Entrepreneurship and Regional Development, Vol. 7 No. 1, pp. 41-62.

Destatis (2020), "Statistisches Bundesamt [Federal statistical office]", available at: https://www. destatis.de/EN/Home/_node.html (accessed 5 August 2020).

Díez-Martín, F., Blanco-González, A. and Prado-Román, C. (2016), "Explaining nation-wide differences in entrepreneurial activity: alegitimacy perspective", The International Entrepreneurship and Management Journal, Vol. 12 No. 4, pp. 1079-1102.

Dileo, I. and García Pereiro, T. (2019), “Assessing the impact of individual and context factors on the entrepreneurial process: a cross-country multilevel approach", The International Entrepreneurship and Management Journal, Vol. 15 No. 4, pp. 1393-1441.

Drakopoulou Dodd, S., Jack, S. and Anderson, A.R. (2013), "From admiration to abhorrence: the contentious appeal of entrepreneurship across Europe", Entrepreneurship and Regional Development, Vol. 25 Nos 1-2, pp. 69-89.

Dustmann, C., Fitzenberger, B., Schönberg, U. and Spitz-Oener, A. (2014), "From sick man of Europe to economic superstar: Germany's resurgent economy", The Journal of Economic Perspectives, Vol. 28 No. 1, pp. 167-188.

Elsbach, K.D. (1994), "Managing organizational legitimacy in the California cattle industry: the construction and effectiveness of verbal accounts", Administrative Science Quarterly, Vol. 39 No. 1 , pp. $57-88$.

Elsbach, K.D. (2003), "Relating physical environment to self-categorizations: identity threat and affirmation in a non-territorial office space", Administrative Science Quarterly, Vol. 48 No. 4, pp. 622-654.

Espinoza-Benavides, J. and Díaz, D. (2019), “The entrepreneurial profile after failure”, International Journal of Entrepreneurial Behavior and Research, Vol. 25 No. 8, pp. 1634-1651.

Eurobarometer (2002), "Flash barometer entrepreneurship no. 134. results and comments", available at: https:/ec.europa.eu/commfrontoffice/publicopinion/flash/fl134_en.pdf (accessed 6 February 2020).

Feldman, M.P. (2001), "The entrepreneurial event revisited: firm formation in a regional context", Industrial and Corporate Change, Vol. 10 No. 4, pp. 861-891.

Fernández-Serrano, J., Berbegal, V., Velasco, F. and Expósito, A. (2018), "Efficient entrepreneurial culture: a cross-country analysis of developed countries", The International Entrepreneurship and Management Journal, Vol. 14 No. 1, pp. 105-127.

Fredland, J.E. and Morris, C.E. (1976), "A cross section analysis of small business failure”, American Journal of Small Business, Vol. 1 No. 1, pp. 7-18.

Freytag, A. and Thurik, R. (2007), "Entrepreneurship and its determinants in a cross-country setting", Journal of Evolutionary Economics, Vol. 17 No. 2, pp. 117-131.

Fritsch, M. and Falck, O. (2007), "New business formation by industry over space and time: a multidimensional analysis", Regional Studies, Vol. 41 No. 2, pp. 157-172.

Fritsch, M. and Mueller, P. (2004), "Effects of new business formation on regional development over time”, Regional Studies, Vol. 38 No. 8, pp. 961-975. 
Fritsch, M. and Mueller, P. (2008), “The effect of new business formation on regional development over time: the case of Germany", Journal of Small Business Economics, Vol. 30 No. 1, pp. 15-29.

Fritsch, M. and Wyrwich, M. (2014), "The long persistence of regional levels of entrepreneurship: Germany 1925 to 2005”, Regional Studies, Vol. 48 No. 6, pp. 955-973.

Fritsch, M. and Wyrwich, M. (2017), "The effect of entrepreneurship on economic development:an empirical analysis using regional entrepreneurship”, Journal of Economic Geography, Vol. 17 No. 1, pp. 157-189.

Fuller, C.M., Simmering, M.J., Atinc, G., Atinc, Y. and Babin, B.J. (2014), "Common method variance detection in business research", Journal of Business Research, Vol. 69 No. 8, pp. 3192-3198.

Garud, R., Schildt, H.A. and Lant, T.K. (2014), "Entrepreneurial storytelling, future expectations, and the paradox of legitimacy", Organization Science, Vol. 25 No. 2, pp. 1479-1492.

GEM (Global Entrepreneurship Monitor) (2020), “GEM 2019/2020 global report. GEM consortium”, available at: https://www.gemconsortium.org/latest-global-reports (accessed 30 July 2020).

Grichnik, D. (2008), "Risky choices in new venture decisions: evidence from Germany and the US", Journal of International Entrepreneurship, Vol. 6 No. 1, pp. 22-47.

Grilo, I. and Irigoyen, J.M. (2006), "Entrepreneurship in the EU: to wish and not to be", Journal of Small BusinessEconomics, Vol. 26 No. 4, pp. 305-318.

Harman, H.H. (1967), Modern Factor Analysis, The University of Chicago Press, Chicago, IL.

Headd, B. (2003), "Redefining business success: distinguishing between closure and failure", Journal of Small Business Economics, Vol. 21 No. 1, pp. 51-61.

Hofstede, G.H. (1980), Culture's Consequences: Comparing Values, Behaviors, Institutions, and Organizations Across Nations, Sage, Thousand Oaks, CA.

Hofstede, G.H. (1983), "The cultural relativity of organizational practices and theories", Journal of International Business Studies, Vol. 14 No. 2, pp. 75-89.

Hundt, C. and Sternberg, R. (2014), "How did the economic crisis influence new firm creation?", Jahrbücherfür Nationalökonomie und Statistik, Vol. 234 No. 6, pp. 723-756.

Inglehart, R. (1997), Modernisation and Postmodernisation: Cultural, Economic and Political Change in 43 Societies, Princeton University Press, Princeton, NJ.

Johnson, P. and Parker, S.C. (1996), "Spatial variation in the determinants and effects of firm births and deaths", Regional Studies, Vol. 30 No. 7, pp. 679-688.

JUNIOR (2017), "Junior programme. JUNIOR", available at: https://www.junior-programme.de/de/ junior-schueler-erleben-wirtschaft/ (accessed 17 May 2017).

Kalden, J.N., Cunningham, J. and Anderson, A.R. (2017), "The social status of entrepreneurs: contrasting German perspectives", The International Journal of Entrepreneurship and Innovation, Vol. 18 No. 2, pp. 91-104.

Kautonen, T., Down, S. and Minniti, M. (2014), “Ageing and entrepreneurial preferences”, Journal of Small Business Economics, Vol. 42 No. 3, pp. 579-594.

KfW (Kreditanstalt für Wiederaufbau) (2018), "KfW-Gründungsmonitor 2018. KfW research", available at: https://www.kfw.de/PDF/Download-Center/Konzernthemen/Research/PDF-DokumenteGründungsmonitor/KfW-Gruendungsmonitor-2018.pdf (accessed 5 November 2018).

Kibler, E. and Kautonen, T. (2016), "The moral legitimacy of entrepreneurs: an analysis of early-stage entrepreneurship across 26 countries”, International Small Business Journal, Vol. 34 No. 1, pp. 34-50.

Kibler, E., Kautonen, T. and Fink, M. (2014), "Regional social legitimacy of entrepreneurship: implications for entrepreneurial intention and start-up behavior", Regional Studies, Vol. 48 No. 6, pp. 995-1015.

Kibler, E., Mandl, C., Kautonen, T. and Berger, E.S.C. (2017), “Attributes of legitimate venture failure impressions”, Journal of Business Venturing, Vol. 32 No. 2, pp. 145-161. 
IJEBR

26,8

1882
Koe, W.-L. (2016), "The relationship between individual entrepreneurial orientation (IEO) and entrepreneurial intention”, Journal of Global Entrepreneurship Research, Vol. 6 No. 13, pp. 1-11.

Kraus, S., Clauß, T., Breier, M., Gast, J., Zardini, A. and Tiberius, V. (2020), "The economics of COVID-19: initial empirical evidence on how family firms in five European countries cope with the corona crisis", International Journal of Entrepreneurial Behavior and Research, Vol. 26 No. 5, pp. 1067-1092.

Kuckertz, A., Berger, E.S.C. and Allmendinger, M.P. (2015), "What drives entrepreneurship? A configurational analysis of the determinants of entrepreneurship in innovation-driven economies", Business Administration Review, Vol. 75 No. 4, pp. 273-288.

Kuckertz, A., Kollmann, T., Krell, P. and Stöckmann, C. (2017), "Understanding, differentiating, and measuring opportunity recognition and opportunity exploitation", International Journal of Entrepreneurial Behavior and Research, Vol. 23 No. 1, pp. 78-97.

Kuckertz, A., Brändle, L., Gaudig, A., Hinderer, S., Morales Reyes, C.A., Prochotta, A., Steinbrink, K.M. and Berger, E.S.C. (2020), "Startups in times of crisis-a rapid response to the COVID-19 pandemic", Journal of Business Venturing Insights, Vol. 13, June, e00169.

Kuckertz, A. (2013), "Entrepreneurship education-status quo and prospective developments", Journal of Entrepreneurship Education, Vol. 16, pp. 59-71.

Landier, A. (2005), Entrepreneurship and the Stigma of Failure, New York University Press, New York, NY.

Lattacher, W. and Wdowiak, M.A. (2020), "Entrepreneurial learning from failure. A systematic review", International Journal of Entrepreneurial Behavior and Research, Vol. 25 No. 5, pp. 1093-1131.

Lee, S.-H., Yamakawa, Y., Peng, M.W. and Barney, J.B. (2011), "How do bankruptcy laws affect entrepreneurship development around the world?", Journal of Business Venturing, Vol. 26 No. 5, pp. 505-520.

Liguori, E. and Winkler, C. (2020), "From offline to online: challenges and opportunities for entrepreneurship education following the COVID-19 pandemic", Entrepreneurship Education and Pedagogy, Vol. 3 No. 4, pp. 346-351.

Mandl, C., Berger, E.S.C. and Kuckertz, A. (2016), 'Do you plead guilty? Exploring entrepreneurs' sensemaking-behavior link after business failure", Journal of Business Venturing Insights, Vol. 5 No. 9, pp. 9-13.

McGrath, R.G. (1999), "Falling forward: real options reasoning and entrepreneurial failure", Academy of Management Review, Vol. 24 No. 1, pp. 13-30.

McKeon, H., Johnston, K. and Henry, C. (2004), "Multinational companies as a source of entrepreneurial learning: example from the IT sector in Ireland", Education + Training, Vol. 46 Nos 8-9, pp. 433-443.

Meccheri, N. and Pelloni, G. (2006), "Rural entrepreneurs and institutional assistance: an empirical study from mountainous Italy", Entrepreneurship and Regional Development, Vol. 18 No. 5, pp. 371-392.

Middleton, K.W., Padilla-Meléndez, A., Locket, N., Quesada-Pallarès, C. and Jack, S. (2020), "The university as an entrepreneurial learning space", International Journal of Entrepreneurial Behavior and Research, Vol. 26 No. 5, pp. 887-909.

Mittelstands Monitor (2007), "MittelstandsMonitor 2007. Den Aufschwungfestigen, Beschäftigung und Investitionenweitervorantreiben [Consolidating the upswing, further boosting employment and investment]", available at: https://www.kfw.de/Download-Center/Konzernthemen/Research/ PDF-Dokumente-MittelstandsMonitor/MiMo_2007_lang_D.pdf (accessed 5 February 2020).

Mueller, S.L. and Thomas, A.S. (2001), "Culture and entrepreneurial potential: anine country study of locus of control and innovativeness", Journal of Business Venturing, Vol. 16 No. 1, pp. 51-75.

Mueller, P., Van Stel, A. and Storey, D.J. (2008), "The effect of new firm formation on regional development over time: the case of Great Britain”, Journal of Small Business Economics, Vol. 30 No. 1, pp. 59-71. 
Mueller, P. (2006), "Exploring the knowledge filter: how entrepreneurship and university-industry relationships drive economic growth", Research Policy, Vol. 35 No. 10, pp. 1499-1508.

Neck, H.M. and Greene, P.G. (2011), "Entrepreneurship education: known worlds and frontiers", Journal of Small Business Management, Vol. 49 No. 1, pp. 55-70.

Neter, J., Kutner, M.H., Wasserman, W. and Nachtsheim, C.J. (1996), Applied Linear Statistical Models, McGraw-Hill, New York, NY.

North, D.C. (1990), Institutions, Institutional Change and Economic Performance, Cambridge University Press, Cambridge.

Panwar, R., Hansen, E. and Kozak, R. (2014), "Evaluating social and environmental issues by integrating the legitimacy gap with expectational gaps: an empirical assessment of the forest industry", Business and Society, Vol. 53 No. 6, pp. 853-875.

Piegeler, M. and Röhl, K.H. (2015), "Gründungsförderung in Deutschland: Ein Aktionsplan gegen sinkende Gründerzahlen, [Support for start-ups in Germany: An action plan to combat declining numbers of start-ups]", Policy Paper 17, German Economic Institute (IW), Cologne, pp. 3-24.

Pierre-André, J. (2019), "The regional variations of entrepreneurial dynamism: a mixed methods study”, Entrepreneurship and Regional Development, Vol. 31 Nos 9-10, pp. 874-907.

Podsakoff, P.M., MacKenzie, S.B., Lee, J.Y. and Podsakoff, N.P. (2003), "Common method biases in behavioral research: a critical review of the literature and recommended remedies", Journal of Applied Psychology, Vol. 88 No. 5, pp. 879-903.

Politis, D. and Gabrielsson, J. (2009), “Entrepreneurs' attitude towards failure: an experiential learning approach", International Journal of Entrepreneurial Behavior and Research, Vol. 15 No. 4, pp. 364-383.

Reynolds, P., Storey, D. and Westhead, P. (1994), "Regional variations in new firm formation—special issue", Regional Studies, Vol. 28 No. 4, pp. 343-456.

Röhl, K.H. (2016), "Entrepreneurial culture and startups: could a cultural shift in favour of entrepreneurship lead to more innovative start-ups?”, Policy Paper 2/2016E, German Economic Institute (IW), Cologne.

Röhl, K.H. (2019), "Entrepreneurship: a comparative study of the interplay of culture and personality from a regional perspective?", Journal of Small Business and Entrepreneurship, Vol. 31 No. 2, pp. 119-139.

Ruda, W., Martin, T.A., Arnold, W. and Danko, B. (2012), "Comparing start-up propensities and entrepreneurship characteristics of students in Russia and Germany", Acta PolytechnicaHungarica, Vol. 9 No. 3, pp. 97-113.

Scott, M. and Lewis, J. (1984), "Re-thinking entrepreneurial failure", in Lewis, J., Stanworth, J. and Gibb, A. (Eds), Success and Failure in Small Business, Gower, Hampshire, pp. 29-56.

Shane, S. (1993), "Cultural influences on national rates of innovation", Journal of Business Venturing, Vol. 8 No. 1, pp. 59-73.

Shepherd, D.A. and Haynie, J.M. (2011), "Venture failure, stigma, and impression management: aselfverification, self-determination view", Strategic Entrepreneurship Journal, Vol. 5 No. 2, pp. 178-197.

Shepherd, D.A. and Patzelt, H. (2017), Trailblazing in Entrepreneurship: Creating New Paths for Understanding the Field, Palgrave Macmillan, Cham.

Shepherd, D.A., Douglas, E.J. and Shanley, M. (2000), "New venture survival: ignorance, external shocks, and risk reduction strategies", Journal of Business Venturing, Vol. 15 Nos 5-6, pp. 393-410.

Shepherd, D.A. (2003), "Learning from business failure: propositions of grief recovery for the selfemployed", Academy of Management Review, Vol. 28 No. 2, pp. 318-328.

Simmons, S.A., Wiklund, J. and Levie, J. (2014), "Stigma and business failure: implications for entrepreneurs' career choices", Journal of Small Business Economics, Vol. 42 No. 3, pp. 485-505.
Entrepreneurial failure

1883 
IJEBR

26,8

1884

Singh, S., Corner, P. and Pavlovich, K. (2007), "Coping with entrepreneurial failure", Journal of Management and Organization, Vol. 13 No. 4, pp. 331-344.

Singh, S., Corner, P. and Pavlovich, K. (2015), "Failed, not finished: anarrative approach to understanding venture failure stigmatization", Journal of Business Venturing, Vol. 30 No. 1, pp. 150-166.

Stam, E. (2007), "Why butterflies don't leave: locational behavior of entrepreneurial firms", Economic Geography, Vol. 83 No. 1, pp. 27-50.

Stenholm, P., Acs, Z. and Wuebker, R. (2013), "Exploring country-level institutional arrangements on the rate and type of entrepreneurial activity", Journal of Business Venturing, Vol. 28 No. 1, pp. 176-193.

Sternberg, R. and Rocha, H.O. (2007), "Why entrepreneurship is a regional event: theoretical arguments, empirical evidence, and policy consequences", in Minniti, M. (Ed.), Entrepreneurship: The Engine of Growth, Praeger, Westport/CT, London, pp. 215-238.

Sternberg, R., Bergmann, H. and Lückgen, I. (2004), "Global entrepreneurship monitorUnternehmensgründungen im internationalen Vergleich: Länderbericht Deutschland 2003”, working paper, University of Cologne, Cologne, Germany, 4 March.

Sternberg, R., Gorynia-Pfeffer, N., Wallisch, M., Baharian, A., Stolz, L. and von Bloh, J. (2020), "Global entrepreneurship monitor-Unternehmensgründungen im internationalen Vergleich: Länderbericht Deutschland 2019/20", working paper, RKW Rationalisation and Innovation Centre of the German Economy e. V., April 2020.

Stuetzer, M., Obschonka, M., Brixy, U., Sternberg, R. and Cantner, U. (2014), "Regional characteristics, opportunity perception and entrepreneurial activities", Journal of Small Business Economics, Vol. 42 No. 2, pp. 221-244.

Tamásy, C. (2006), "Determinants of regional entrepreneurship dynamics in contemporary Germany: a conceptual and empirical analysis", Regional Studies, Vol. 40 No. 4, pp. 365-384.

Ucbasaran, D., Shepherd, D.A., Lockett, A. and Lyon, S.J. (2013), "Life after business failure: the process and consequences of business failure for entrepreneurs", Journal of Management, Vol. 39 No. 1, pp. 163-202.

Valliere, D. (2017), "Belief patterns of entrepreneurship: exploring cross-cultural logics", International Journal of Entrepreneurial Behavior and Research, Vol. 23 No. 2, pp. 1355-2554.

Van Stel, A. and Storey, D. (2004), "The link between firm births and job creation: is there a upas tree effect?", Regional Studies, Vol. 38 No. 8, pp. 893-909.

Wagner, J. and Sternberg, R. (2004), "Start-up activities, individual characteristics, and the regional milieu: lessons for entrepreneurship support policies from German micro data", The Annals of Regional Science, Vol. 38 No. 2, pp. 219-240.

Wagner, J. (2002), “Taking a second chance: entrepreneurial restarts in germany”, IZA Discussion Paper 417, Institute for the Study of Labor, Bonn, January 2002.

Walsh, G.S. and Cunningham, J.A. (2016), "Business failure and entrepreneurship: emergence, evolution and future research", Found Trends Entrepreneurship, Vol. 12 No. 3, pp. 163-285.

Walsh, G.S. and Cunningham, J.A. (2017), "Regenerative failure and attribution:examining the underlying processes affecting entrepreneurial learning", International Journal of Entrepreneurial Behavior and Research, Vol. 23 No. 4, pp. 688-707.

Warren, L. (2004), "A systemic approach to entrepreneurial learning”, Systems Research and Behavioral Science, Vol. 21 No. 1, pp. 3-16.

Weiss, J., Anisimova, T. and Shirokova, G. (2019), "The translation of entrepreneurial intention into start-up behaviour: the moderating role of regional social capital”, International Small Business Journal, Vol. 37 No. 5, pp. 473-501.

Welter, F. (2007), "Entrepreneurship in west and east Germany", International Journal of Entrepreneurship and Small Business, Vol. 4 No. 2, pp. 97-109. 
Wiklund, J., Baker, T. and Shepherd, D.A. (2010), "The age effect of financial indicators as buffers against liabilities of newness", Journal of Business Venturing, Vol. 25 No. 4, pp. 423-437.

Williamson, O. (2000), "The new institutional economics: taking stock, looking ahead", Journal of Economic Literature, Vol. 38 No. 3, pp. 595-613.

Wyrwich, M., Stuetzer, M. and Sternberg, R. (2016), "Entrepreneurial role models, fear of failure, and institutional approval of entrepreneurship: atale of two regions", Journal of Small Business Economics, Vol. 46 No. 3, pp. 467-492.

Yan, Y. and Guan, J. (2019), "Entrepreneurial ecosystem, entrepreneurial rate and innovation: the moderating role of internet attention", The International Entrepreneurship and Management Journal, Vol. 15 No. 2, pp. 625-650.

\begin{abstract}
About the authors
Andreas Kuckertz is a Professor of Entrepreneurship at the University of Hohenheim in Stuttgart, Germany. Moreover, he serves as the President of FGF e.V., the largest academic association for entrepreneurship, innovation and small and medium-sized enterprises (SMEs) in the Germanspeaking countries. Andreas Kuckertz is the corresponding author and can be contacted at: andreas.kuckertz@uni-hohenheim.de

Elisabeth S.C. Berger is a Lecturer with the University of Hohenheim's entrepreneurship research group in Stuttgart, Germany.

Alicia Prochotta is a Doctoral Student with the University of Hohenheim's entrepreneurship research group in Stuttgart, Germany.
\end{abstract}

For instructions on how to order reprints of this article, please visit our website:

www.emeraldgrouppublishing.com/licensing/reprints.htm

Or contact us for further details: permissions@emeraldinsight.com 